\title{
IS RELIGION UNDERMINED BY EVOLUTIONARY ARGUMENTS?
}

\author{
LOUIS CARUANA
}

Heythrop College, University of London

\begin{abstract}
I examine three major anti-religious arguments that are often proposed in various forms by cognitive and evolutionary scientists, and indicate possible responses to them. A fundamental problem with the entire debate arises because the term "religion" is too vague. So I reformulate the debate in terms of a less vague central concept: faith. Referring mainly to Aquinas on faith, I proceed by evaluating how the previously mentioned cognitive and evolutionary arguments fare when dealing with faith. The results show that some aspects of the concept of faith are in principle beyond the range of evolutionary explanation and some other aspects are not. Nevertheless, an evolutionary account merges smoothly with faith's theological dimensions.
\end{abstract}

This paper deals with the epistemological foundations of religion. The basic question is: "Does evolutionary explanation undermine religion?" To answer this question, I will start by illustrating how evolutionary explanation has been extended from biology, its natural habitat, to religion, its final frontier, according to some. Current studies in this area proceed in their overall approach on the paths already traced by various predecessors that go all the way back to Charles Darwin himself. ${ }^{1}$ I will focus mainly on the current situation. In the first section, I will argue that underneath the arguments issuing from these evolutionary accounts, whether for or against religion, there lies a major problem that often goes unmentioned. This has to do with the very notion of religion. Could it be that more progress becomes possible in this area if, instead of

${ }^{1}$ Typical current studies include Boyer (2001), Atran (2002), Plantinga (2002), Sloan Wilson (2003), Schloss \& Murry (2009). Major precedents include Teilhard de Chardin (1955), and Darwin himself in Darwin (1874). 
working with the central notion of religion, we work with the narrower notion of faith? To explore this sub-question, I dedicate the second section to a clarification of the notion of faith, building up on the foundations set by Aquinas. Then, in the third section, I will determine the extent to which the evolutionary accounts mentioned before apply with more profit to the understanding of faith. My hope is that the analysis will allow me to articulate a plausible version of the notion of faith consistent with evolutionary anthropology.

\section{EVOLUTIONARY ACCOUNTS OF RELIGION}

Although the literature is vast, one may safely say that the core ingredient of this research program is simple. Since evolutionary principles have been successfully applied to explain human biology, they should also be applied to explain religion. These principles include three main elements. In brief, we need random mutation of a hereditary trait that is crucial for survival. Once these three elements are present within a self-replicating system, natural selection occurs in the long run. Of course, for any given organism, there can be many traits that satisfy this triple condition; consequently, natural selection may occur simultaneously at various fronts as regards the same species. For religion to fall within the range of this kind of explanation, it must have some feature that satisfies the triple condition. Hence, evolutionary psychologists interested in offering an evolutionary explanation of religion must first locate an aspect of their object of study that is evolutionarily relevant in this sense. Once they fix this, they will be able to tell a story whereby the presence of this aspect can be seen as the product of natural selection. An evolutionary explanation of religion would thus be available. Two broad camps will be considered: one holds that some aspects of religion are genuinely located within the range of evolutionary explanation. These aspects are adaptive, in the sense that they confer a survival advantage on the organisms that have them. The other camp holds that there is no such evolutionarily relevant aspect of religion. All aspects of religion are neutral. Religion confers neither advantages nor disadvantages for the survival of the organism. ${ }^{2}$

${ }^{2}$ Other kinds of argument are available. For instance, it is also possible to argue that religion confers serious disadvantages for survival, but that these disadvantages are 
Let's start with the adaptive camp. The evolutionarily relevant aspects of religion most commonly referred to in this context are two: one involving supernatural agents, and the other involving super-knowing judges. The first one is the one most widely discussed. Child psychologists have discovered that small infants perceiving moving objects or dots on a screen readily attribute agency to these items. They see purpose everywhere. This is taken to indicate an intrinsic mental procedure constitutive of human nature. To refer to this procedure, researchers use the expression "hypersensitive agency detection device", HADD for short (Atran 2002; Barrett 2004). This expression is somewhat loaded with materialist overtones, especially evident in the term "device." To remain neutral with respect to thorny debates in the philosophy of mind, it is better to use "disposition" rather than "device", with the acronym remaining the same. With this in view, it is not difficult to see how this cognitive feature enhances fitness. Organisms that have it show a strong tendency to believe in the existence of agents when they detect certain kinds of stimuli. They are thus wary of various circumstances - wary of circumstances that are genuinely dangerous and wary also of circumstances that are not. Although this cognitive feature delivers a lot of false positives, it definitely represents the safer strategy. In the long run, it is better to err on the side of being cautious than on the side of being reckless. Some researchers working on HADD proceed then by affirming that religion is essentially constituted by this disposition. It is an extrapolation of HADD. Humans have religious beliefs because they have been naturally selected according to HADD. Those of our ancestors with religion survived. Those without it were filtered off.

Another aspect of religion that is considered in this context is associated with the belief in invisible but super-knowing judges, in other words, the belief that great superhuman forces are observing and judging all that people do. This stance is associated with the origins of morality and cooperation. As has been shown, cooperation within groups can be the result of natural selection when two principles are in operation: kin-selection and reciprocity. This explanation is vulnerable because of one problem. A cooperative group remains vulnerable to free-riders or

counterbalanced by other traits. For lack of space, this kind of argument is not being considered in this paper. 
cheaters: those who receive benefits from the group without contributing. Such instability undermines the survival value of cooperation. Being a cheater, of course, needs the capacity to deceive, and this capacity varies depending on the intelligence of the organisms under consideration. For the hominid family, therefore, it seems that cooperation should have disappeared early on, undermined by ever more effective cheating. The fact that it didn't shows that there's something else in the equation, something that trumps the effect of cheaters. And this is precisely the element that interests us here. The amazingly high degree of cooperation between humans shows that there is some pressure that acts against deception. So we postulate a cause for this pressure: it comes from a belief that, even though other humans are not aware of the cheating, punishment will still be delivered. There are superhuman forces that observe and judge everything people do. Selfishness and cheating must therefore be curbed for fear that such forces will deliver their punishment. The deliverer of such punishment is referred to by various terms, including, for instance, gods, witches, and dead ancestors. ${ }^{3}$ As a corollary, this view entails that ill fortune is a sign of hidden moral misconduct. The bottom line is that humans are religious as an outcome of their being cooperative, and they are cooperative because of an innate primordial belief in the existence of super-knowing agents who ensure that justice is done.

So up to now we have mentioned two possible candidates for an adaptationist view of religion. As I said, defenders of these two candidates form one camp. The other camp consists of those who contest the adaptationist view. They argue that religion in itself offers no survival advantage whatsoever. ${ }^{4}$ They argue that religion is an epiphenomenon, a by-product that in itself has no adaptive value but is associated with some traits that do. The term often used in this context is "spandrel." This is an architectural term referring to a structure that arises within a building not because it is needed but because of other structures that are. An example of a biological spandrel is the sound of the heartbeat. What is evolutionarily relevant as regards the heart is the way it pumps

${ }^{3}$ In this section, I draw from, Johnson \& Bering (2009). The argument is not that this evolutionarily-relevant aspect is the only feature that ensures cooperation. There may be other factors that block cheating or enhance cooperation. The argument, however, does say that the idea of a super-knowing punisher is the major relevant feature.

${ }^{4}$ A very clear case is made in Boyer (2001). 
blood efficiently, not the sound it makes. Hence the production of sound gets a free ride, as it were, all along the evolutionary development of the heart. It is not filtered off because, as regards natural selection, it is invisible. In the same way, religion may be a free rider. It may be a phenomenon that exists simply because it "rides" on other human features that confer survival advantages, while itself being irrelevant from the point of view of natural selection. Some researchers have tried to gather evidence and build a case for this possibility, but expert scientific opinion shows no clear agreement on whether religion is indeed epiphenomenal. One might always object, for instance, that new evidence may turn up showing that some survival advantages are indeed associated with the sound of heart-beat. And this shows that all epiphenomena are judged to be so only because of current limitations in evolutionary knowledge. Nevertheless, in line with the argument of this paper, I would like to take this view as the third major possible account. I think it is reasonable to say that religion could be an epiphenomenon.

These three possible evolutionary accounts of religion are often presented with anti-religious strings attached. Researchers working in this area often present their results as undermining the validity of religion in some way or other. They take their results to show that religious claims are unacceptable and that religious practice is either detrimental to society or utterly futile. How do they do this? ${ }^{5}$ Their critique takes various forms. Consider the first typical argument:

(A1) Religion is unacceptable because it is essentially a consequence of HADD, a mental operation that exaggerates the detection of agency.

The force of this critique arises from the fact that HADD is unreliable. It exaggerates. And it is precisely because of this exaggerating tendency that it had been selected. On closer scrutiny, this objection loses a lot of its impact. Its weakness arises mainly because the critique makes no reference to the obvious fact that agent-detection happens all the time in the life of a normal human. Moreover, there is no clear dividing line between cases where agent-detection is readily verifiable and cases where

\footnotetext{
${ }^{5}$ For further details on these arguments, see Murray (2009).
} 
agent-detection is not readily verifiable. There is no clear dividing line between the use of HADD as regards not-yet-observed entities and its use as regards unobservable entities. Calling HADD unreliable should make us abandon it even for everyday scenarios. But abandoning HADD is not possible. We have stipulated at the very start of the argument that this disposition is advantageous for survival. So argument A1 should not worry defenders of religion too much.

Consider another typical criticism:

(A2) Religion is unacceptable because its central beliefs are not caused by the entities they talk about; they arise from mechanisms that function independently from these entities.

This critique has bite only within the context of epistemological externalism. Within this context, knowledge claims and beliefs must have a proper causal relationship with the mind-independent world they talk about. Argument A2 presses the point that religion, as described by evolutionary theories, is not caused by the objects it talks about. And this undermines belief about them. Those who want to block this critique have at least one clear option. They can press the point that, if we assume that religious beliefs have been naturally selected, we are saying that they confer an advantage on those who have them. Take vision as an example. Vision confers evolutionary advantages on those who have it. It is not just vision that confers these advantages. It must be truthful vision. $\mathrm{Mu}-$ tations that result in organisms that see things where there are no things to be seen are dead ends. Such organisms are filtered off. Hence, vision's adaptive attribute is related to the realism involved in seeing. This example can be extended to reason and to the mind in general. Correct reasoning confers evolutionary advantages because inferring and deducing correctly makes good reasoners survive where confused reasoners die off. It should be evident, therefore, that once we assume at the start that having religious beliefs is adaptive, we are committed to some kind of efficiency with respect to these beliefs. If kidneys and hearts are effective in their domain, it is very plausible to hold that vision and intelligence are also. And, if religion is a special expression of affective and intelligent engagement with the world, then religion can be considered acceptable on these grounds. 
A third critique of religion arises from the evolutionary account that takes it to be a useless by-product. In short, the objection could be phrased as follows.

(A3) Religion is unacceptable because it is epiphenomenal.

The basic point is that religious beliefs haven't proved their mettle by going through the filtering processes that shaped hominid evolution. They are just irrelevant fossils of primordial, mental meanderings that never washed away. Can a defence of religion be mounted against this argument? A possible move could start from the fact that A3 dismisses much more than religion. It obliges us to consider all non-instrumental thinking epiphenomenal. And this leads to all kinds of problems. What constitutes human nature is vastly determined by non-instrumental, symbolic thinking - by poetic and metaphorical language, art, music, literature and sculpture. Once we accept A3, it becomes obvious that evolutionary theories can account for only a very small section of the human phenomenon. It would be naïve to claim that such an account exhausts all there is to say about human beings. It would therefore be equally naive to argue that religion is unacceptable because it lies beyond the range of evolutionary explanation.

None of the arguments and counter-arguments discussed so far is a knock-down argument. They all invite further discussion and analysis. The main reason to include them here is not primarily to give the reader a taste of what is going on in this area of philosophy. It is rather to highlight an overriding problem with all such arguments. They all assume that the object of discussion, namely religion, is clear and precise enough to allow fruitful debates about it. But this assumption is misleading. To see why this is so, I propose excavating below the surface of these arguments so as to uncover what is happening at the level of the very definition of religion.

Let me characterize the individual steps taken by typical anti-religious evolutionary psychologists that end up arguing in the form of A1, $\mathrm{A} 2$ or $\mathrm{A} 3$.

(S1) They first acknowledge, consciously or unconsciously, a "received concept" of religion, call it R (it is often taken to be 
a complex agglomeration of attitudes, practices, rituals, habits, and so on, many of which can only be described by using vague predicates).

(S2) They extract from $\mathrm{R}$ an aspect that is evolutionarily relevant; call this Q.

(S3) They show how natural selection successfully explains Q.

(S4) They claim that the success of S3 shows either that the really significant aspect of $\mathrm{R}$ is $\mathrm{Q}$; or that we are now, finally, able to define $\mathrm{R}$ properly, namely as $\mathrm{Q}$ (hence, all there is to $\mathrm{R}$ is $\mathrm{Q}$ ).

The basic idea behind this sequence is clear. The general strategy is to move from what may be called a hazy knowledge of something to a clear knowledge of it. What we have here is a refining process. But does the success of S3 really justify the reduction occurring in S4? I argue that it does not.

To see why, consider first, as an example, the love between husband and wife. Since time immemorial, love has been of central importance in human existence: as is evident in literature, drama, art, philosophy and religion. In the nineteenth century, experimental work in France and Germany established that special chemicals are responsible for a kind of communication between different organs within an animal. At the Royal College of Physicians in London, the word "hormone" was then launched as the standard term for these chemicals, and since then immense interest has been generated in various related research fields. As regards the specific issue of human love, the excitement and arousal love involves became understandable as the effect of hormones rushing from cell to cell along the blood stream, coordinating the action, perception and feeling of different parts of the body. Now, if one were to suggest that, because of these discoveries, this empirical account should be enshrined as the real meaning of love, not many would be convinced - and with good reason. The depth of meaning associated with love remains to a very great extent completely unaffected by these empirical discoveries, important as they are. When love between a husband and wife is described as real, nothing is being said about the chemicals involved in that experience. What is being said is situated at another level. The scientific discovery changes the broad concept and experience of love only at one 
tiny spot, if it does at all. And it makes no sense to have reductionism smuggled into the story.

The case of religion is similar. Suppose that evolutionary psychology has established to everyone's satisfaction that religion is definitely either an instance of HADD or an extrapolation of the idea of a super-knowing punisher, as explained above. Should this claim oblige us to reduce the concept to this? Should we say that now we have discovered what religion really is? On the strength of the analogy with the example above, the answer is no. Nothing stops us from accepting both the newly discovered aspect and the other associated meanings of the term not in direct contradiction with the newly discovered aspects. This is as far as we can go with the analogy.

One disanalogy with the example of love is very important. Whereas the empirical substrate of love can be considered a genuine part of the study of love, the case of religion is different. The concept of religion seems to be situated within our conceptual scheme so as to enable us to refer to what people do when they reach out beyond what is empirically graspable. There are, of course, empirically graspable religious body movements and social practices. But the essential feature in religion seems to be the meaning attributed to these empirically graspable features, not the features themselves. Moreover, whereas the concept of love can perhaps be seen as one single concept, usable and reusable in various contexts, the concept of religion is not straightforwardly unified. We need to admit that the term religion is vague in the logical sense. It has no clear boundaries. What we call religions indeed share similarities between them but there is no guarantee that a core of features is shared by all. It is very probable that there is no such common core. The more data cultural anthropology delivers, the more the idea of a common essence of religion seems to drift away; and it is certainly not useful to cover this up by looking away from religions as they are and speculating on how they should be. The concept of religion is like the Wittgensteinian concept of a game, or even worse - worse because some religions involve a very high degree of self-reflection and self-adjustment, which implies an ongoing transformation of their very nature.

Should we give up hope then as regards trying to understand religion with the various modes of inquiry at our disposal? Not necessarily. I suggest the following strategy. Since religion is such a vast and elusive 
category, a safer method is to carve out a smaller, more manageable unit and work with that. Faith is one of these units. The aim of this inquiry, therefore, becomes to determine the insights that can be drawn from evolutionary psychology as regards faith. The first step in this new venture will take us right across to the other end of the spectrum. From the scientifically charged explanations discussed so far, we move to theologically charged accounts of faith. This preliminary discussion will establish a good working definition of faith. Only when we have this can we determine whether evolutionary explanations can be successful in this context or not.

\section{THE NATURE OF FAITH}

To answer the question "What is faith?" we can adopt various strategies. One of them is to ask typical religious persons for their own version of the nature of faith. This method delivers a phenomenology of faith, and what these people report would constitute, as it were, first-hand data with respect to which theories may be constructed and evaluated. The result of such a phenomenology of faith, however, suffers from its high degree of subjectivity and context-dependence. Another strategy is to determine the structure of the concept of faith. One does this by analyzing the grammar of faith-involving linguistic expressions. We determine where and how these expressions behave properly and where and how they break down. This is the typical method of analytic philosophers. ${ }^{6}$ Yet another method is to look back and see what the major thinkers of the past have written on this topic and start from there. This strategy is not completely different from the other two. The major philosophers of the past, of course, were themselves employing phenomenology or conceptual analysis, or both. In this paper, I am adopting the third strategy, concentrating on Aquinas, with the occasional allusion to the second, especially when indicating how technical terms of past centuries translate into those in current use. ${ }^{7}$

\footnotetext{
${ }^{6}$ For examples of this method, see Audi (2008), Wolterstorff (1990).

${ }^{7}$ Some evolutionary psychologists would, of course, find this method unacceptable. They present their views as the correct account of religion. They insist that what practitioners of religion like Aquinas say about it is irrelevant (e.g. Boyer 2001, p. 262-3). But
} 
Thomas Aquinas builds his account of faith on two foundations: Aristotelian psychology, involving the categories of will and intellect, and Augustinian theological ideas, summed up in the formula "to believe is nothing other than to think with assent". ${ }^{8}$ I will summarize the Thomist view in three points. First, he accepts Aristotle's view that the human intellect can sometimes be determined by the will. This does not mean that, for Aristotle, I am entitled to believe the world to be so just because I want it to be so. He is referring to cases when we assent to a proposition even though we do not have enough evidence for it. In this context, we can take assent to mean, quite simply, agreement with or compliance to a proposal. ${ }^{9}$ For Aquinas, faith is such an act. It is a case of the will determining the intellect. In normal circumstances, will-motivated assent is partial or conditional. We say, "I assent to this claim because it's probably true" or "I assent to this claim because it is a logical consequence of another claim that I take to be true." In the case of faith, however, the assent is complete and unconditional. Believers declare, "We believe in God". They don't declare, "We take it that there's probably a God." In what way does the assent of faith differ from normal assent? There are two main differences. The first difference concerns intellectual dissatisfaction. This kind of dissatisfaction arises when a person assents to a claim that, as far

this is mistaken. It is as mistaken as its opposite, namely that only practitioners of religion can explain religion. The complexity of religion should make us beware of simplistic reductionism. Truth should be welcome whatever its source. The more viewpoints on the issue, the better. Moreover, we should not forget that Boyer and his colleagues are themselves explainable by sociology of science in ways that may perhaps surprise them.

8 "Credere, nihil aliud est, quam cum assensione cogitare". St Augustine, On the Predestination of Saints, Book I, chapter 5 (Patrologia Latina, vol. 44, col. 963).

${ }^{9}$ This key-term "assent" is certainly related to the term "acceptance," which is quite prominent in current philosophical discussions. Their meaning, however, is not the same. Accepting that $p$ means endorsing $p$ deliberately, or taking $p$ to be true for the sake of the argument, even if you do not believe it. Assenting to $p$ has wider scope; you can be assenting to $p$ even if you are not at present conscious of doing so. Further analysis is needed to situate assent with respect to acceptance and belief, but this lies beyond the scope of this paper. Audi (2008) is a good starting point. Moreover, I here take the will to refer to a person's faculty of choice - certainly not to a part of the person's body. Evolutionary psychologists would perhaps want to undermine such an Aristotelian category by breaking it down into small parts, perhaps by endorsing some form of modularity of mind. This will not affect the account of faith I describe here. Whatever the background structure of willing, it is undeniable that people sometimes will to believe a given proposition. 
as that person knows, doesn't enjoy sufficient evidential support. How do believers deal with this? For normal cases of assent, this dissatisfaction is appeased by the believer seeking more evidence. For faith, however, the dissatisfaction is pacified by the believer acknowledging that he or she is acting out of trust. The believer believes not because of evidence, but because of the authority of God who is the guarantor of revelation. In faith, the will directs the intellect to assent because of its trustful submission to God who is recognized as infallible and omniscient. There is a categorical difference then between the certitude associated with natural sources of knowledge and that associated with faith. The former is the fruit of evidence and demonstration; the latter the fruit of risk that one deliberately takes on because of a loving relationship.

The second point to highlight is the way Aquinas exposes the tension that exists in the very concept of faith. This point is fundamental for my argument in this paper, because in cognitive accounts of religion it is often neglected. Aquinas insists that faith involves not only the person who has it but also God whose extra help in this matter is indispensable. The object of the assent involves a set of truths that go beyond the grasp of natural reason or of science as we understand it today - Aquinas is here referring to truths like the truth of the Triune nature of God. Consequently, the act of assent must involve a contribution that comes from beyond the natural capacities of humans. Moreover, there is no neat, two-tier structure within the idea of faith. Aquinas denies that there is a purely human contribution, presumably explainable by evolutionary psychology, and then an added divine push. To be consistent with biblical texts, he insists that God is responsible for the entire act of faith:

The Pelagians held that this cause [i.e. the internal cause that moves man inwardly to assent to matters of faith] was just man's freewill, and consequently they said that the beginning of faith is from ourselves, inasmuch as it is certainly in our power to be ready to assent to things which are of faith, but that the consummation of faith is from God, from whom are proposed the things we have to believe. But this is false. Since man, by assenting to matters of faith, is raised above his nature, this must be added to him from some supernatural principle moving him inwardly; and this is God. Therefore faith, as regards the assent, which is the chief act of faith, is from God moving man inwardly by grace. ${ }^{10}$

${ }^{10}$ In this paper, quotes from Aquinas are my translation, using the online version of Summa Theologiae in Corpus Thomisticum (Fundación Tomás de Aquino, 2000-2009), 
The third important point to highlight becomes evident when Aquinas moves beyond the idea of faith as involving assent to the idea of faith as a virtue. Up to now, I have focused on how he equates faith with the act of believing particular truths of revelation. This is only part of the story. For a comprehensive grasp of his view, we need to add his distinction between fides and credere. Fides is a virtue while credere is the act of assenting to a proposition. In general, a virtue is an excellence of a human faculty or habit directed towards the good. Faith is a twofold excellence. It involves the excellence of the intellect as it seeks absolute truth, namely God; and it involves also the excellence of the will as it seeks absolute good, again God. He writes: "For since to believe is an act of the intellect assenting to the truth at the command of the will, two things are required for this act to be perfect. One of these is that the intellect should infallibly tend to its good, which is the true; while the other is that it should be infallibly directed to the last end, by which the will assents to the true. And both of these are to be found in the act of mature faith." 11

With these three points in mind, we can summarize Aquinas's overall view using his own words: "to believe is an act of intellect assenting to the divine truth by virtue of the command of the will as moved by God through grace". ${ }^{12}$

It is useful here to digress a little by supplementing the above points with some ideas from the works of Martin Luther. Although the major, overarching debate in Luther's writings on faith concerns justification,

abbreviated henceforth as ST. For hidden nuances, the reader may want to consult the original Latin, included in footnotes. This text is from ST 2a2ae Q6 a1: "Hanc autem causam Pelagiani ponebant solum liberum arbitrium hominis, et propter hoc dicebant quod initium fidei est ex nobis, inquantum scilicet ex nobis est quod parati sumus ad assentiendum his quae sunt fidei; sed consummatio fidei est a Deo, per quem nobis proponuntur ea quae credere debemus. Sed hoc est falsum. Quia cum homo, assentiendo his quae sunt fidei, elevetur supra naturam suam, oportet quod hoc insit ei ex supernaturali principio interius movente, quod est Deus. Et ideo fides quantum ad assensum, qui est principalis actus fidei, est a Deo interius movente per gratiam."

${ }_{11}$ "Cum enim credere sit actus intellectus assentientis vero ex imperio voluntatis, ad hoc quod iste actus sit perfectus duo requiruntur. Quorum unum est ut infallibiliter intellectus tendat in suum bonum, quod est verum, aliud autem est ut infallibiliter ordinetur ad ultimum finem, propter quem voluntas assentit vero. Et utrumque invenitur in actu fidei formatae." ST 2a2ae Q4 a5.

${ }^{12}$ ST 2a2ae Q2 a9: "credere est actus intellectus assentientis veritati divinae ex imperio voluntatis a Deo motae per gratiam, et sic subiacet libero arbitrio in ordine ad Deum." 
a debate which is primarily theological, one can identify a valuable core that is essentially philosophical and complementary to the Thomistic views expressed above. First of all, for Luther, faith is in stark contrast to works. His major claim is that it is wrong to attempt to worship God according to works only. Consider a typical claim of his: "this is the reason why our theology is certain: it snatches us away from ourselves, so that we do not depend on our own strength, conscience, experience, person or works but depend on that which is outside ourselves, that is, on the promise and truth of God, which cannot deceive." ${ }^{13}$ We have here a clear expression of the idea that faith in the Word of God is not within our power. Faith demands that we let go of what our human knowledge delivers so as to cling only to the testimony of Christ. Secondly, Luther emphasizes the fact that faith offers freedom from human laws and traditions. The coercion and constraint of human laws make individuals obey through fear, concerned mainly with themselves. Faith has the effect of liberating such people so that they may obey and indeed engage in good works in selflessness and love. Luther writes: "the just man [i.e. the one with faith] lives as though he had no need of the Law to admonish, urge, and constrain him; but spontaneously, without any legal constraint, he does more than the Law requires." ${ }^{14}$ Thirdly, Luther defends a notion of faith that is not concerned primarily with believing a number of propositions. He retrieved the original idea of faith as used by St Paul, namely the idea that faith is a characteristic of the entire person who is open to God. It refers to a state of a person rather than an attitude towards a set of propositions. The person of faith, on this account, is faithful to God, does God's will, hopes in God, believes what God says, and so on. Faith refers to the entire package. For Luther, "faith is God's work in us, that changes us and gives new birth from God [...] Faith is a living, bold trust in God's grace, so certain of God's favor that it would risk death a thousand times trusting in it." 15

Luther's focus is essentially on the lived faith. He is highlighting the third aspect of Aquinas' view, namely fides as distinct from credere. Both

${ }^{13}$ Luther (1955-1967), vol. 26, p. 387. See also Zachman (1993).

${ }^{14}$ Luther (1955-1967), vol. 27, p. 96.

${ }^{15}$ Vermischte Deutsche Schriften, ed. J.K. Irmischer Vol. 63 (Erlangen: Heyder and Zimmer, 1854), pp.124-125, trans. R.E. Smith (1994), URL: http://www.iclnet.org/pub/ resources/text/wittenberg/luther/luther-faith.txt 
authors converge on this point, a fact that highlights its importance. Of course, the brief sketch of faith presented up to now can barely do justice to Aquinas and Luther, and it is too short to include the various refinements their positions received since they were written. Nevertheless, even the points mentioned here are enough to indicate the basic, essential characteristics of faith, characteristics that ensure the right kind of coherence with biblical texts. So I will proceed by focusing on the area where the two views overlap. Whether expressed in terms of virtue or in terms of a way of life, faith for both can be described as follows.

(F) Faith is a state or attribute of the person as a whole, involving an exercise of freedom and a special divine initiative.

I will build on this formula, adding here just one further clarification: that the state referred to in this statement can be manifested in various ways. It can be manifested when the person assents to explicit propositions. It can be manifested when the person participates in organized celebrations or liturgies. It can be manifested when the person makes decisions. Moreover, if there is no manifestation of a person's faith, one cannot draw the conclusion that it is absent. All these observations follow from the idea of habit, of which faith is a special kind.

\section{EVOLUTIONARY ACCOUNTS OF FAITH}

I will now bring in the three evolutionary explanations discussed in section one: first, the account of religion as an instance of HADD; secondly, the account of religion as an extrapolation of the idea of a super-knowing punisher; and third, the account of religion as a fortuitous by-product with no relevance for fitness. Are these accounts valid and useful when considering faith as defined in statement F? There are three elements within this definition. It says that faith is an attribute of the person as a whole; it mentions freedom; and it mentions God's initiative.

The first element seems to be the most readily amenable to an evolutionary account. It speaks of faith as an attribute of the person as a whole, and thus it includes the various dispositions the person can acquire over time. Such dispositions, of course, can be of the individual person, or of 
the particular group or tradition the person belongs to, or even of the species as a whole. As regards this aspect of faith, therefore, an evolutionary account can have great significance. It is certainly plausible to argue that HADD is responsible to some extent for a disposition to believe in the existence of a cause of the universe. Whether this disposition needs to be labelled with the term "hypersensitive", as if it involves an unjustified excess of something, may be disputed. But the point here is that there is no obvious contradiction between the evolutionary account involving HADD and this aspect of the notion of faith. The same thing can be said as regards the second evolutionary explanation, the one invoking the belief in a super-knowing punisher. It is plausible to argue that such a belief in a super-knowing punisher, which is a fruit of natural selection, is, to some extent, responsible for a disposition to believe in the afterlife and in the last judgment. There is nothing intrinsically contradictory in making this claim, as long as we do not add the reductive clause that faith is this disposition and nothing else. If we move on now to those evolutionary psychologists who want to take the third account and argue that religion emerged as an epiphenomenon, we can see also that they will have no direct clash with the concept of faith. They are just saying that faith is not a biological phenomenon, in the strict sense. Presumably, they would say the same thing as regards Beethoven's composing of the $9^{\text {th }}$ Symphony, Michelangelo's painting of the Sistine Chapel, and Darwin's conceiving of evolution through natural selection. They would acknowledge that what happens at the level of culture lies largely beyond the explanatory reach of evolution by natural selection. This is in line with the way some philosophers of biology explain the specificity of Homo sapiens, whose appearance represents a crucial junction: the point where evolution gave rise to a system that is no longer within its range, a system that floats freely (Sober 1992). So, all in all, it seems plausible to hold that the first ingredient of definition F can merge smoothly with all three evolutionary accounts.

We move on now to the second and third elements within F. They are: the claim that faith involves an exercise of freedom and the claim that it involves a special divine initiative. Can these two elements of faith be accounted for by an evolutionary explanation?

The short answer is no to both. The first element introduces the idea of freedom; and freedom refers to the capacity of rational agents to 
choose consciously one course of action from among various alternatives. This point introduces one of the major distinctions between the empirical and the human sciences. The objects of study for the human sciences differ radically from those for the empirical sciences. The objects of study for the human sciences are themselves epistemic agents. They can be influenced by their own awareness of the results of the very inquiry that is allegedly describing them objectively. To further describe this phenomenon, I will use the established term "reflexivity" (Geuss 1981; Rosenberg 2007). In general, reflexivity occurs when a theory is such that the dissemination of its results will jeopardize its confirmation. Reflexivity occurs, for instance, when a theory predicts that oil prices will fall; that very prediction then makes agents in society act to falsify it by raising prices. ${ }^{16}$ Such reflexivity embedded within the human sciences has given rise to the idea that these sciences should not be conceived of on the model of physics. They are inherently different. They are useless for prediction but indispensable for emancipation. They present before the human agents they study a mirror in which these agents can see themselves together with the ideologies that determine their action. The agents are thus enabled to look objectively on what till then had been unconscious, and to accept, reject or change their guiding principles. As regards faith, my claim is that reflexivity is central. It is not just present. It is constitutive of faith's very nature. Any hint that individuals have been coerced to be persons of faith, undermines their status of being persons of faith. ${ }^{17}$ Since faith is an instance of freedom, evolutionary explanations can, at best, only be partial.

If we consider the other ingredient of the notion of faith, namely the requirement that it involves divine initiative, the situation vis-à-vis any

\footnotetext{
${ }^{16}$ It is interesting to recall that, in some domains, physics itself had to undergo revisions because of this very point. Paul Dirac explained the origin of indeterminacy in quantum physics by resorting to a similar scenario. There is a level at which the photons used to measure the position of a micro-particle displace the micro-particle in the very process of measuring. Hence classical physics needs radical revision, at least at this level.

${ }^{17}$ The centrality of freedom here points towards an interesting corollary about the role of reason. Individuals who feel obliged to believe that God exists because they consider themselves coerced by the necessity of logical arguments are not people of faith. Faith is possible only through freedom and trust in God.
} 
possible evolutionary explanation is the same. The requirement here is that a correct understanding of faith includes God's action as the first mover of the person's process of assent. The reason for this, let us recall, is that, by faith, the person has access to truths that are not accessible naturally. Aquinas concludes: "therefore faith, as regards assent, which is the chief act of faith, is from God moving man inwardly by grace." Notice, first of all, that this element indicates how the concept of religious faith is not a mere extension of the general notion of faith, evident when we talk of someone, say, who has faith that a colleague will succeed. The notion of religious faith is to some extent sui generis because persons who have such faith have it on trust - trusting the very "object" of their faith. They do not first seek a convincing argument for the existence of God and then start having faith by trusting him. There is only one act involved. And God is acknowledged to be both its source and end. Now, it is clear that any evolutionary explanation can only range over what humans do. It cannot cover also what God does. So one might want to call a halt here to the entire inquiry. One might object to the idea of including God within the very definition of faith. Once God is in there, explanation is jeopardized. In other words, the very idea of explanation should be seen as requiring that God not be part of the explanandum. Various reasons could be brought forward for this requirement. Invoking God is not part of empirical science; invoking God is essentially explaining the unfamiliar by referring to something that is even less familiar; and invoking God offers false satisfaction, as it tends to undercut the motivation to seek the structure of secondary causes. This objection cuts deep. It shows that the evolutionary psychologist disagrees here with the very definition of faith we started with. At this juncture of the debate, there is apparently little more that can be done. The believer has one definition of faith. The evolutionary psychologist has another. They often seem to be talking about the same thing, but in fact they are not.

Is it really as bad as that? I would like to remove this impasse by drawing some insight from the clause Aquinas adds, apparently casually, in the statement just quoted. The clause in question is the qualification regarding the assent of faith. Aquinas writes: "faith, as regards assent, which is the chief act of faith, [...]." He calls the assent the chief act of faith, principalis actus fidei. I take him to indicate thereby that there are other aspects of faith apart from the one he calls principal, other aspects 
that he would call secondary. And I propose that among these other aspects there are some features that are perfectly explainable via evolutionary accounts.

To support this claim, I offer a sketch of a synthetic view, merging an evolutionary account with the theologically charged understanding of faith described in statement $F$. This can be derived from an analogy between faith and morals. As regards acting morally, one is sometimes predisposed to do the good by a spontaneous desire or emotion, as when a mother helps her child automatically. But acting in this way doesn't show the heights of moral virtue. In fact, acting in this way reduces the moral value, the praiseworthiness, of the act. The mother can be said to be fully mature in her moral virtue when she helps her child wilfully, after a deliberate acceptance of her natural and primordial, affective drive. She helps her child even, say, when he has grown up and is not responding favourably to her anymore. Notice that the predisposition of a mother to help her child is indeed explainable via evolutionary considerations - in the same way as the same disposition of many other animals towards their offspring.

Now what has been said as regards morals can also be said as regards faith. The human person can be predisposed to believe truths about the divine and to live accordingly. Such predispositions can be explainable as arising out of features like HADD, or out of the idea of a super-knowing punisher, or via some other feature not yet discovered. When the person has beliefs of this kind and lives accordingly, we can legitimately call that person a person of faith, but only in a very superficial or rudimentary sense. Such a person acts religiously because compelled to do so by dispositions for which he or she is not responsible. Being religious in this way certainly doesn't show the heights of the virtue of faith, and some would even say that, strictly speaking, the person here would only have a shadow of faith, not faith itself. Be that as it may, the crucial step occurs when the person starts to accept deliberately the general drive these dispositions suggest, and finally arrives at accepting the divine with the right motivation, namely love of God. ${ }^{18}$ My argument here resembles the

${ }^{18} \mathrm{I}$ am not suggesting that there is literally a definite stage in a person's life when desires change into conceptualized desires, allowing the person to choose to act in line or not in line with them. The transition is gradual as the individual grows to maturity; and, even then, desires and dispositions become conceptualized only when they are the focus 
thinking of Aquinas, but is not exactly like his. Consider his concise way of putting it:

[...] in moral virtues, a passion which precedes choice diminishes the praiseworthiness of the virtuous act. For just as a man ought to perform acts of moral virtue on account of the judgment of reason, and not on account of a passion, so ought he to believe matters of faith, not because of human reason, but because of Divine authority. ${ }^{19}$

Aquinas is here using the analogy between morals and faith. He is effectively drawing the analogy by saying that passion is to reason (for morals) as reason is to trust in God (for faith). So, in his version, passion, as such, does not appear on the side of faith. I am suggesting that it could. A passion may indeed be involved in faith. Of course, the term "passion" here is to be understood in the medieval sense, namely as a received disposition. I am suggesting that primordial dispositions, hammered into the human species through millennia of natural selection, are the rudiments of faith. I concede that the dimension I am introducing could be contestable. The main contention could arise because the preambles of faith, praeambula fidei, have traditionally been associated exclusively with a set of truths, truths that natural reason can know of God independently of revelation..$^{20}$ They were not taken to include dispositions. My suggestion is in fact saying that these preambles include not only a set of truths but also some basic somatic dispositions. In other words, I'm urging that some bodily habits are conducive to the faith, and are presupposed by it. Such bodily habits are the material, as it were, on which faith flourishes. The suggestion is justified to the extent that faith, as expressed in statement $\mathrm{F}$, is a state or attribute of the person as a whole: body, mind, community. If this final step in my reasoning is correct, the overall bottom line is that evolutionary explanations can indeed

of attention. It is arguable that this change from being desire-driven to being reasondriven occurs also gradually all along the evolution of the Hominidae family.

${ }^{19}$ ST 2a2ae Q2 a10: "[...] passio praecedens electionem in virtutibus moralibus diminuit laudem virtuosi actus. Sicut enim homo actus virtutum moralium debet exercere propter iudicium rationis, non propter passionem; ita credere debet homo ea quae sunt fidei non propter rationem humanam, sed propter auctoritatem divinam."

${ }^{20}$ The nature of the praeambula fidei is not a completely settled issue. For current contrasting views, see McInerny (2006), Wippel (2000). 
merge smoothly with a theological understanding of faith, even though they account for some of its aspects and not all.

\section{CONCLUSION}

My original aim in this paper was to answer the question: "Does evolutionary explanation undermine religion?" I started with an overview of the way evolutionary explanation is being extended beyond biology to cover also the area of religion. I highlighted the three major arguments that are often used to undermine religion, but I argued that each of the three attacks has a possible counter-argument that neutralizes it. The fundamental problem beneath these arguments and counterarguments is that "religion" is too broad a term to allow valuable analysis. So I proceeded by reducing some of the vagueness inherent within the inquiry. I did this by concentrating on the notion of faith rather than religion. To secure a working definition of faith, suitable for the kind of inquiry engaged in here, I extracted its major ingredients from Aquinas and proceeded by evaluating how the previously mentioned evolutionary accounts of religion fare when dealing with faith. The results showed that, although parts of the concept of faith are in principle beyond the range of evolutionary explanation, other parts are not. I supported this further by sketching an account of faith wherein an evolutionary explanation merges smoothly with its theological aspects. My original question therefore has not been answered but transformed. And as regards its new version "Does evolutionary explanation undermine the notion of faith?" the answer is no.

Acknowledgments. I thank the following for their comments on previous drafts of this paper: Gerard J. Hughes, Justin Barrett, Kelly James Clark, Dani Rabinowitz, and members of the Centre for Philosophy of Religion at the University of Notre Dame. 


\section{BIBLIOGRAPHY}

Atran, Scott. In Gods we Trust: the Evolutionary Landscape of Religion. Oxford: Oxford University Press, 2002.

Audi, Robert. "Belief, faith, and acceptance." International Journal for the Philosophy of Religion, 63 (2008): 87-102.

Barrett, Justin. Why Would Anyone Believe in God? Walnut Creek, CA: AltaMira Press, 2004.

Boyer, Pascal. Religion Explained. The Evolutionary Origins of Religious Thought. New York: Basic Books, 2001.

Darwin, Charles. The Descent of Man and Selection in Relation to Sex, $2^{\text {nd }}$ ed. New York: American Home Library, 1874.

Geuss, R. The Idea of a Critical Theory. Cambridge: Cambridge University Press, 1981.

Johnson, D. \& Bering, J. "Hand of God, Mind of Man: punishment and cognition in the evolution of cooperation." In: Schloss \& Murray (2009), 26-43.

Luther, Martin. Luther's Works, ed. J. Pelikan \& H.T. Lehman, Philadelphia: Fortress Press, 1955-1967.

McInerny Ralph M. Praeambula Fidei: Thomism and the God of the Philosophers. Washington, D.C.: Catholic University of America Press, 2006.

Murray, M.J. "Scientific Explanations of Religion and the Justification of Religious Belief." In: Schloss \& Murray (2009), 168-78.

Plantinga, Alvin. "Evolutionary argument against naturalism." In: Naturalism defeated? edited by J. Beilby, 1-12. Ithaca, NY: Cornell University Press, 2002.

Rosenberg, A. Philosophy of Social Science. Westview Press, 2007.

Schloss, J. \& Murray, M.J. (eds). The Believing Primate. Oxford: Oxford University Press, 2009.

Sloan Wilson, David. Darwin's Cathedral: Evolution, Religion, and the Nature of Society. Chicago: University Of Chicago Press, 2003.

Sober, Elliott. "Models of Cultural Evolution.” In: Trees of Life: Essays in the Philosophy of Biology, edited by P. Griffiths, 17-40. Dordrecht: Kluwer, 1992.

Teilhard de Chardin, Pierre. Le Phénomène humaine. Paris: Éditions de Seuil, 1955; trans. B. Wall, The Phenomenon of Man. London: Collins, 1959.

Thomas Aquinas. Summa Theologiae. In: Corpus Thomisticum. Fundación Tomás de Aquino, 2000-2009. URL: http://www.corpusthomisticum.org/

Wippel, J.F. The Metaphysical Thought of Thomas Aquinas. Washington, D.C.: Catholic University of America Press, 2000.

Wolterstorff, N. “The assurance of faith." Faith and Philosophy 7(4) (1990): 396417.

Zachman, R. The Assurance of Faith: Conscience in the Theology of Martin Luther and John Calvin. Minneapolis: Fortress Press, 1993. 